\title{
Characterisation of lactic acid bacteria isolated from artisanal Egyptian Ras cheese
}

\author{
Eman H.E. AYAD ${ }^{a}$, Nadia OMRAN ${ }^{b}$, Morsi EL-SODA ${ }^{b *}$ \\ a Food Science Department, Faculty of Agriculture, Saba Bacha, Alexandria University, \\ Alexandria, Egypt \\ b Dairy Science and Technology Department, Faculty of Agriculture, Alexandria University, \\ Alexandria, Egypt
}

Received 4 November 2005 - Accepted 30 March 2006

\begin{abstract}
Wild LAB (188 strains) isolated from artisanal Egyptian Ras cheese including Lactococcus (15), Lactobacillus (95), Enterococcus (77) and Pediococcus (1) were characterised for biochemical and production characteristics related to their technological performance. All Lactococcus (subsp. lactis and cremoris) were able to grow at $40{ }^{\circ} \mathrm{C}$ and in the presence of $4 \% \mathrm{NaCl}$. Six L. lactis subsp. lactis, one strain of subsp. cremoris and 95\% of Lactobacillus strains were salt-tolerant, as they were able to grow in $6.5 \% \mathrm{NaCl}$. Twenty percent of lactococci, $21 \%$ of lactobacilli and $43 \%$ of enterococci showed a medium acidification rate, one strain of Lb. delbrueckii subsp. lactis and E. faecium exhibited a fast acidifying ability. Most lactobacilli revealed higher aminopeptidase and autolytic activity when compared with other strains. Twenty-seven percent of tested strains appeared to have antimicrobial activity and the highest inhibitory activity was observed among enterococci (13\% of 188 strains). Exopolysaccharides (capsule) were detected in $4.3 \%$ of the lactobacilli. Most strains were able to produce a high yield of biomass after growth, showed a good biomass separation and were not affected by lyophilisation treatment. Strains which showed outstanding characteristics were screened for their flavour-forming abilities in milk cultures. Ninety-one strains, 7 Lactococcus, 52 Lactobacillus and 32 Enterococcus, were selected for an application in Ras cheese according to their production and technological criteria: salt tolerance, ability to grow at 40$45{ }^{\circ} \mathrm{C}$, acid production, proteolytic activity, flavour and bacteriocin production. These strains are currently being tested in pilot-scale cheese trials to improve Egyptian Ras cheese.
\end{abstract}

Egyptian Ras cheese / starter culture / wild LAB / acidification / aminopeptidase / autolysis / bacteriocin / exopolysaccharide / flavour

摘要 - 从手工制作埃及拉斯干酪中分离出的乳酸菌特性研究。从手工制作的埃及拉斯干酪 (Ras cheese) 中共分离出 188 株野生乳酸菌, 根据这些菌株的生化和生长特性确定这些菌株 分别为乳球菌 (Lactococcus) 15 株, 乳杆菌 (Lactobacillus) 95 株, 肠球菌 (Enterococcus) 77 株, 片球菌 (Pediococcus) 1 株。所有的乳球菌 (乳酸亚种和乳脂亚种) 都可以在 $40{ }^{\circ} \mathrm{C}$ 和 $4 \%$ $\mathrm{NaCl}$ 的环境中生长。其中 6 株乳酸乳球菌乳亚种 (Lc. lactis subsp. lactis)、1 株乳酸乳球菌乳 脂亚种 (Lc. lactis. subsp. cremoris) 和 $95 \%$ 的乳杆菌具有耐盐性, 可以在 $6.5 \% \mathrm{NaCl}$ 环境中 生长。 $20 \%$ 的乳球菌、 $21 \%$ 的乳杆菌和 $43 \%$ 的肠球菌产酸速率适中, 其中一株德式乳杆 菌乳亚种 (Lb. delbrueckii subsp. lactis) 和一株屎肠球菌 (E.faecium) 的产酸速率较快。与其他 乳酸菌相比大多数乳杆菌分泌氨基肽酶活力较高, 菌体的自溶能力较强。实验证明 $27 \%$ 受 试菌株具有明显的抗菌活性, 其中肠球菌 (占 188 株的 13\%) 的抑菌活力最高。 $4.3 \%$ 的乳

* Corresponding authors (通讯作者): morsi_elsoda@hotmail.com; eayad@hotmail.com 
杆菌能够分泌胞外多糖 ( 英膜多糖)。经体外培养后大多数菌株生长状态良好, 生物量较 高, 分离后的菌体经过冻干处理后, 活性没有受到影响。将那些具有突出特性的菌株在乳 基培养基中单独培养, 从中篮选出具有显著产香能力的菌株。根据标准的拉斯干酪生产工 艺和技术要求, 将这些菌株应用于拉斯午酪的生产中, 以耐盐性、在 $40 \sim 45^{\circ} \mathrm{C}$ 下的生长 情况、产酸量、蛋白水解能力、产香能力和产细菌素能力作为评价指标, 从中篮选出 91 株 乳酸菌, 其中乳球菌 7 株、乳杆菌 52 株、肠球菌 32 株。这些菌株已经用于中试规模的研 究中, 用以改进埃及拉斯干酪的品质特性。

\section{埃及拉斯干酪 / 发酵剂 / 野生乳杆菌 / 酸化 / 氨基肽酶 / 自溶 / 细菌素 / 胞外多糖 / 风味}

Résumé - Caractérisation de bactéries lactiques isolées à partir du fromage traditionnel égyptien «Ras ». Des souches sauvages de Lactococcus, Lactobacillus, Enterococcus et Pediococcus ont été isolées à partir du fromage égyptien « Ras ». Les souches furent ensuite caractérisées d'après leur aptitude technologique et biochimique. Lactococcus lactis subsp. lactis et cremoris se développaient à $40{ }^{\circ} \mathrm{C}$ en présence de $4 \% \mathrm{Nacl}$. Six souches de Lactococcus lactis subsp. lactis et une souche de Lactococcus lactis subsp. cremoris ainsi que $95 \%$ des souches de Lactobacillus étaient résistantes au chlorure de sodium à des concentrations de 6,5\%. Environ $20 \%$ des lactocoques, $21 \%$ des lactobacilles et $43 \%$ des entérocoques montraient une activité acidifiante moyenne. La majorité des lactobacilles possédaient une forte activité autolytique et aminopeptidasique. Vingt-sept pourcent des souches testées montraient une activité inhibitrice vis-à-vis des autres souches. La plus forte activité inhibitrice a été révélée chez les entérocoques. La production d'exopolysaccharides a été démontrée chez $4,8 \%$ des lactobacilles. En règle générale, les souches qui montraient des caractéristiques intéressantes ont ensuite était sélectionnées pour la production de composés d'arôme dans le lait. Quatre-vingt-onze souches ont été isolées et sélectionnées pour la fabrication de fromage Ras en fonction de leur tolérance au sel, croissance à $40-45^{\circ} \mathrm{C}$, production d'acide, activité protéolytique, production d'arômes et de bactériocines. Ces souches seront testées à l'échelle pilote pour fabriquer du fromage Ras.

fromage Ras / souche sauvage / bactérie lactique / levain / acidification / aminopeptidase / autolyse / bactériocine / exopolysaccharide / flaveur

\section{INTRODUCTION}

Ras cheese is the main traditional hard cheese in Egypt; it is similar to the Greek variety "Kefalotyri" [33]. A full description of the manufacture, ripening and chemical composition of Ras cheese is reviewed by Abou-Donia [1]. Generally, it is manufactured in a high proportion under artisanal conditions, mainly from raw cow's milk or a mixture of cow's and buffalo's milk without using starter cultures [26]. A mixture of cow's and goat's milk has also been used for making Ras cheese [15]. In such production, fermentation and ripening occurs by the interaction of different wild flora present in raw milk and the surrounding environment. Therefore, the "biodiversity" of LAB involved in cheese production is considered a fundamental factor for the maintenance of the characteristic features and quality of Ras cheese.

Recently, the new Egyptian standards for hard cheese, 2001 [14], published by the
Egyptian organisation for standardisation and quality control, indicated that Ras cheese must be made from pasteurised milk. These standards are aiming to produce cheese under improved hygienic conditions, showing consistent and better quality. That means starter cultures should be added to pasteurised milk prior to the cheese manufacture. Therefore, there is a great need for new starter cultures to use in the production of Ras cheese.

Identification, characterisation and selection of wild LAB from traditional cheese made all around the world in a natural way has been considered in the search for new industrially important cultures [4, $7,41]$. Often, wild strains are adapted to specialised niches, which have evolved with minor or major changes of the genotype and phenotype, in dairy industries. The use of such strains offers great potential for new applications or for existing processes [21]. 
In our university, research work was aimed at improving the manufacture of Ras cheese. The typical Ras cheeses made from raw milk were evaluated according to their sensory evaluation, rheological, physicochemical and microbiological characteristics and flavour formation to be able to manufacture a typical Ras cheese from pasteurised milk and starter cultures [3,6]. For the development of new starter cultures suitable for Ras cheese, several wild LAB were isolated from market Ras cheese and identified, then kept in the culture collection of the Faculty of Agriculture, Alexandria University (FAAU) [17]. The aim of the present work is to characterise LAB associated with artisanal Egyptian Ras cheese with unique features such as salt tolerance, proteolytic activity, acid production, aroma and bacteriocin production in order to select them as starter cultures to improve Ras cheese flavour.

\section{MATERIALS AND METHODS}

\subsection{Origin of strains}

A total of 188 wild LAB strains obtained from the culture collection of FAAU were tested in this study. All strains originated from traditional Ras cheese with artisanal production from local factories in the delta region. These strains belong to several genera of LAB (Tab. I); Lactococcus and Enterococcus strains were grown in M17 medium (Biolife, Milano, Italy; Terzaghi and Sandine [39]), while Lactobacillus and Pediococcus were grown in MRS medium (Biolife, Milano, Italy; De Man et al. [13]), at the optimum growth temperature; $30{ }^{\circ} \mathrm{C}$ for Lactococcus, $30-37^{\circ} \mathrm{C}$ for mesophilic lactobacilli and $42{ }^{\circ} \mathrm{C}$ for thermophilic lactobacilli.

\subsection{Technological characteristics of strains}

\subsubsection{Growth characteristics of strains}

The ability of strains to grow at 10, 30, 40 and $45{ }^{\circ} \mathrm{C}$ was examined in suitable medium (see above) for $48 \mathrm{~h}$. The growth was followed by measuring the optical density at $650 \mathrm{~nm}\left(\mathrm{OD}_{650}\right)$ using a spectrophotometer (NOVA SPEC II, pharmacia LKB Biotech., UK). The sensitivity to salt of the strains was determined by following the growth of strains in suitable medium at optimum growth temperatures in the presence of $1,2,4$ and $6.5 \% \mathrm{NaCl}$. The production of carbon dioxide from glucose was carried out; $1 \mathrm{~mL}$ of the strain was inoculated in $2 \mathrm{~mL}$ MRS agar at $40-45^{\circ} \mathrm{C}$; after $1 \mathrm{~h}, 2 \mathrm{~mL}$ agar $(15 \%)$ was added as an agar plug and incubated at $37^{\circ} \mathrm{C}$, then observed for gas production after 2-4 d. A control was carried out using a yeast, Saccharomyces lactis N.C.Y.C. 571, known for the production of carbon dioxide.

\subsubsection{Acidification activity}

The acidification rate was measured by the change in $\mathrm{pH}$ during time in reconstituted skim milk (RSM) at an appropriate temperature. The cultures were considered as fast-, medium- or slow-acidifying when a $\Delta \mathrm{pH}$ of 0.4 units was achieved after 3,35 and $>5 \mathrm{~h}$, respectively.

\subsubsection{Aminopeptidase (AP) activity}

The strains were cultivated and centrifuged $\left(10 \mathrm{~min}, 4000 \times \mathrm{g}, 4^{\circ} \mathrm{C}\right)$, the pellets washed twice and resuspended in potassium phosphate buffer $\left(10 \mathrm{mmol} \cdot \mathrm{L}^{-1}, \mathrm{pH}\right.$ 7.0) and diluted to $\mathrm{OD}_{650}=1.0(\mathrm{ca} .100 \mathrm{mg}$ cell wet weight $\left.\cdot \mathrm{mL}^{-1}\right)$. Cell permeabilisation was carried out as described by Miozzari et al. [31] and the AP activity was measured according to El-Soda and Desmazeaud [18].

\subsubsection{Autolytic activity}

The rate of cell autolysis was measured as described by Thiboutot et al. [40].

\subsubsection{Antagonistic activity}

Antagonistic activity was examined as described by Geis et al. [23]. Cultures belonging to the same genus were interacted together. Each tested strain was applied as inhibitor while another one was taken as an indicator organism. 
Table I. Growth characteristics of strains.

\begin{tabular}{|c|c|c|c|c|c|c|c|}
\hline & \multirow[t]{2}{*}{ Total } & \multicolumn{3}{|c|}{ Growth at } & \multicolumn{2}{|c|}{$\begin{array}{l}\text { Growth with } \\
\mathrm{NaCl}\end{array}$} & \multirow[t]{2}{*}{$\begin{array}{c}\mathrm{CO}_{2} \\
\text { production }\end{array}$} \\
\hline & & 10 & 40 & $45^{\circ} \mathrm{C}$ & $4 \%$ & $6.5 \%$ & \\
\hline Lactococcus & 15 & & & & & & \\
\hline \multirow[t]{3}{*}{ L. lactis subsp. lactis } & 13 & & & & & & \\
\hline & (6) & + & + & - & + & + & - \\
\hline & (7) & + & + & - & + & - & - \\
\hline \multirow[t]{3}{*}{ L. lactis subsp. cremoris } & 2 & & & & & & \\
\hline & (1) & + & + & - & + & - & - \\
\hline & (1) & + & + & - & + & + & - \\
\hline Lactobacillus & 95 & & & & & & \\
\hline $\begin{array}{l}\text { Lb. delbrueckii subsp. } \\
\text { lactis }\end{array}$ & 5 & - & + & + & + & - & - \\
\hline \multirow[t]{4}{*}{ Lb. fermentum } & 16 & & & & & & \\
\hline & (11) & - & + & + & + & + & + \\
\hline & (4) & - & + & + & - & - & + \\
\hline & (1) & + & + & + & + & - & + \\
\hline Lb. rhamnosus & 31 & + & + & + & + & + & - \\
\hline \multirow{3}{*}{$\begin{array}{l}\text { Lb. paracasei subsp. } \\
\text { paracasei }\end{array}$} & 6 & & & & & & \\
\hline & (5) & + & + & + & + & + & - \\
\hline & (1) & + & + & - & + & + & - \\
\hline Lb. pentosus & 10 & + & + & - & + & + & - \\
\hline \multirow[t]{6}{*}{ Lb. plantarum } & 21 & & & & & & \\
\hline & (12) & + & + & - & + & + & - \\
\hline & (5) & + & + & + & + & + & - \\
\hline & (1) & + & + & + & + & + & + \\
\hline & (1) & + & + & - & + & + & + \\
\hline & (2) & - & + & - & + & + & + \\
\hline Lb. brevis & 3 & + & + & - & + & + & + \\
\hline Lb. acidophilus & 1 & + & + & + & + & + & - \\
\hline \multirow[t]{3}{*}{ Lb. salivarius } & 2 & & & & & & \\
\hline & (1) & - & + & + & + & + & + \\
\hline & (1) & - & + & - & + & + & - \\
\hline Enterococcus & 77 & & & & & & \\
\hline E. faecium & 59 & + & + & + & + & + & - \\
\hline E. durans & 5 & + & + & + & + & - & - \\
\hline E. faecalis & 9 & + & + & + & + & + & - \\
\hline E. avium & 2 & + & + & + & + & + & - \\
\hline Pediococcus & 1 & & & & & & \\
\hline Ped.pentosaceus & 1 & + & + & + & + & - & - \\
\hline Total & 188 & & & & & & \\
\hline
\end{tabular}




\subsubsection{Exopolysaccharide (EPS) production}

Strains were tested for slime formation using the inoculated loop method [29]. The positive strains were tested for capsule production with phase contrast microscopy (Zeiss Microscope, Germany) according to the method of Prescoll et al. [34].

\subsection{Production characteristics of strains}

Biomass production was determined as described by Gerhardt [24]. According to the cell dry weight $\left(\mathrm{CDW} \mathrm{mg} \cdot \mathrm{L}^{-1}\right)$, the strains were divided into three groups; good $\geq 1.30 \mathrm{mg} \cdot \mathrm{L}^{-1}$, fair $1.29-0.6 \mathrm{mg} \cdot \mathrm{L}^{-1}$ and poor $<0.6 \mathrm{mg} \cdot \mathrm{L}^{-1}$.

The optical density of the supernatant that resulted after the centrifugation (10 min, $4000 \times g, 4^{\circ} \mathrm{C}$ ) of the growth media was measured at $650 \mathrm{~nm}$ and used to express the biomass separation; a zero reading was taken as an indication for excellent separation, $\mathrm{OD}_{650}(0-0.1)$ indicated a good separation, $\mathrm{OD}_{650}(0.2-0.3)$ and more than 0.3 indicated a fair and poor separation, respectively.

The obtained pellets were resuspended in RSM (10\% w/v) fortified with $7 \%$ sucrose and were subjected to freeze-drying using a Labconco Freeze-dryer system (Labconco, MO, USA) as described by ElSoda et al. [20] to determine the stability of lyophilised cultures. The acidification activity of freeze-dried and untreated cultures was followed and the cultures were grouped into three classes (good, $\leq 1 \mathrm{~h}$; fair, $\leq 1.5 \mathrm{~h}$; poor, $>2 \mathrm{~h}$ ) depending on the difference in the required time needed to drop the $\mathrm{pH}$ by 0.4 units.

The strains were tested in triplicate for the various above characteristics.

\subsection{Flavour production}

Individual strains were pre-grown for $16 \mathrm{~h}$ at $30^{\circ} \mathrm{C}$ in $\mathrm{RSM}(10 \% \mathrm{w} / \mathrm{v})$ containing $0.1 \%$ yeast extract; $1 \%$ of each culture was added to $100 \mathrm{~mL}$ skimmed UHT milk. Sensory evaluation was carried out after incubation at an optimum temperature for $48 \mathrm{~h}$ by 7 to 10 graders. The intensity of flavour attributes was scored on a scale of: 1, slightly; 2, moderate; 3 , strong; 4, very strong.

\section{RESULTS AND DISCUSSION}

\subsection{Technological characteristics of strains}

LAB isolated from artisanal Ras cheese (188 strains), listed in Table I, were characterised; Lactobacillus (50.5\%) and Enterococcus $(41 \%)$ were the predominant genera, with Lactococcus (8\%) and Pediococcus $(0.5 \%)$ being associated with Ras cheese. Several species of lactobacilli were present; Lb. rhamnosus $32.6 \%$, Lb. plantarum $22.1 \%, L b$. fermentum $16.8 \%, L b$. pentosus $10.5 \%$ and other species $18.0 \%$. A high number of enterococci were present in Ras cheese; E. faecium $(76.6 \%)$ was the predominant species, E. faecalis $(11.7 \%)$ and other species represented $11.7 \%$ of the strains. However, in several cheeses produced from raw milk, enterococci were found to have a relevant role in the ripening process $[22,36]$. From a technological point of view, certain species seem to play a fundamental role in the production of typical artisanal Ras cheese, and therefore were tested.

\subsubsection{Growth characteristics}

All lactococci (Lc. subsp. lactis and cremoris) were able to grow at 10,30 and $40{ }^{\circ} \mathrm{C}$ and in the presence of 1,2 and $4 \%$ $\mathrm{NaCl}$ (Tab. I). Forty-six percent of $L c$. subsp. lactis and one strain of $L c$. subsp. cremoris were able to grow in a medium supplemented with $6.5 \% \mathrm{NaCl}$, which reflects salt tolerance in comparison with the usual milk-fermenting strains of lactococci [38].

Most lactobacilli (Lb. rhamnosus, Lb. fermentum and Lb. plantarum) were heterofermentative. Eighty percent of $L b$. plantarum did not produce $\mathrm{CO}_{2}$, as they are grouped with facultatively heterofermentative lactobacilli [28]. The strains also included a few homofermentative lactobacilli: one $L b$. acidophilus, $2 \mathrm{Lb}$. salivarius 
and 5 Lb. delbrueckii subsp. lactis. Some mesophilic lactobacilli, e.g. Lb. paracasei and $L b$. plantarum were able to grow at 40 and $45^{\circ} \mathrm{C}$, and the thermophilic lactobacilli strains; one $L b$. acidophilus and one strain of $L b$. fermentum were able to grow at $10{ }^{\circ} \mathrm{C}$ (Tab. I), which is rather unusual for the standard characteristics of these strains [42]. Ninety-five percent of lactobacilli were salt-tolerant: they were able to grow in a medium supplemented with $6.5 \%$ $\mathrm{NaCl}$. The physiological properties of enterococci were found to be typical for this group: for example, salt resistance and growth at $10-45^{\circ} \mathrm{C}$ [36].

Salt levels in Ras cheese generally range from 4-6\% [3] and during manufacturing the coagulum is cut into small pieces and stirred at $45^{\circ} \mathrm{C}$ for $40 \mathrm{~min}$ [26]. The ability of lactococci to grow at 40 and $45^{\circ} \mathrm{C}$, and in the presence of $4-6.5 \% \mathrm{NaCl}$, should make them functional for application in Ras cheese as primary starter cultures, and lactobacilli as adjunct cultures.

\subsubsection{Acidification activity}

Forty-three percent of enterococci, 21\% of lactobacilli and $20 \%$ of lactococci exhibited a medium acidification rate, while one strain of Lb. delbrueckii subsp. lactis and $E$. faecium exhibited a fast acidifying ability. The majority of strains showed a slow rate of acidification (Tab. II and Fig. 1). These results are in agreement with Ayad [4], who indicated that the acidifying activity of several wild lactococci is rather low; and with Sarantinopoulos et al. [36] who found that E. faecium, E. faecalis and E. durans strains were poor acidifiers in milk. Most tested strains of $L b$. plantarum, $L b$. rhamnosus, $L b$. fermentum and $L b$. pentosus showed a slow acidification rate, as they are grouped with facultatively heterofermentative lactobacilli [28]. Since a rapid decrease in $\mathrm{pH}$ during the initial step of cheese preparation is important for coagulation and the reduction of the growth of adventitious microflora, the fastand medium-acidifying strains are useful as primary starters, whereas the poor acidifier strains can be used as adjunct cultures depending on their other properties.

\subsubsection{Aminopeptidase (AP) activity}

Aminopeptidase activity was determined to express the proteolytic activity of strains, and generally was found to be higher for most lactobacilli (1-100 unit $\mathrm{OD}_{650}^{-1}$ ) compared with lactococci and pediococci (1-40 unit $\mathrm{OD}_{650}^{-1}$ ) and enterococci $\left(0.8-19\right.$ unit $\left.\mathrm{OD}_{650}^{-1}\right)$. The AP was divided into good, fair and poor according to the activity level of each genus (Tab. II and Fig. 1). The highest AP activity was detected in Lb. rhamnosus, Lb. plantarum, $L b$. case $i$ and $L b$. pentosus. These results are in agreement with Dako et al. [11], who reported that peptidase activities of lactobacilli were generally higher compared with lactococci. L. lactis subsp. lactis showed AP activity higher than L. lactis subsp. cremoris. Forty-seven percent of lactococci, 29\% of lactobacilli and $18 \%$ of enterococci strains exhibited good and fair AP activity (Fig. 1); those strains may have an impact during the ripening of Ras cheese. However, most peptidases have been found to be intracellular [30], reflecting the importance of cell lysis.

\subsubsection{Autolytic activity}

There was a wide diversity in the autolytic activity of tested strains, which led to the classification of the cultures into three groups; poor, fair, and good, according to the autolytic capacity of each genus (Tab. II and Fig. 1). Lactobacilli showed a higher autolysis rate $(0-96 \%)$ when compared with enterococci $(0-66 \%)$ or lactococci strains (1-37\%). These results are comparable with the findings of El-Soda et al. [19], who reported that the autolytic activity of Lactobacillus was higher than other LAB. Forty percent of lactococci, mainly of subsp. lactis, had a fair autolytic activity and the rest of the strains showed poor autolysis. These results are in agreement with Ayad [4], who indicated that several wild lactococci were stable in milk cultures and during cheese ripening. Although the wild lactococci are stable, they harbour active amino-acid-converting enzymes which play a key role in the formation of amino-acid-derived flavour components [5]. Smit et al. [37] reported that the activity 


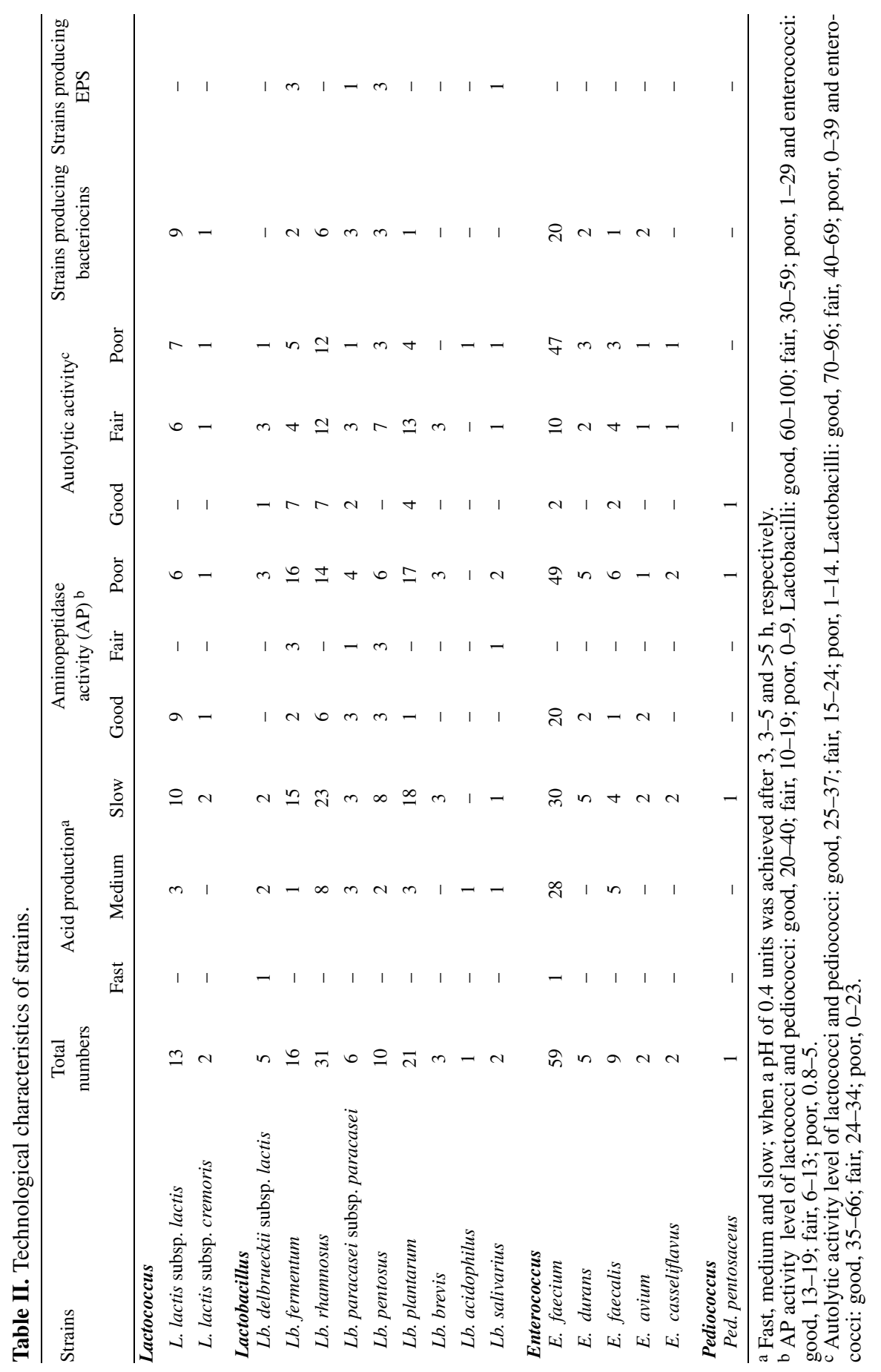



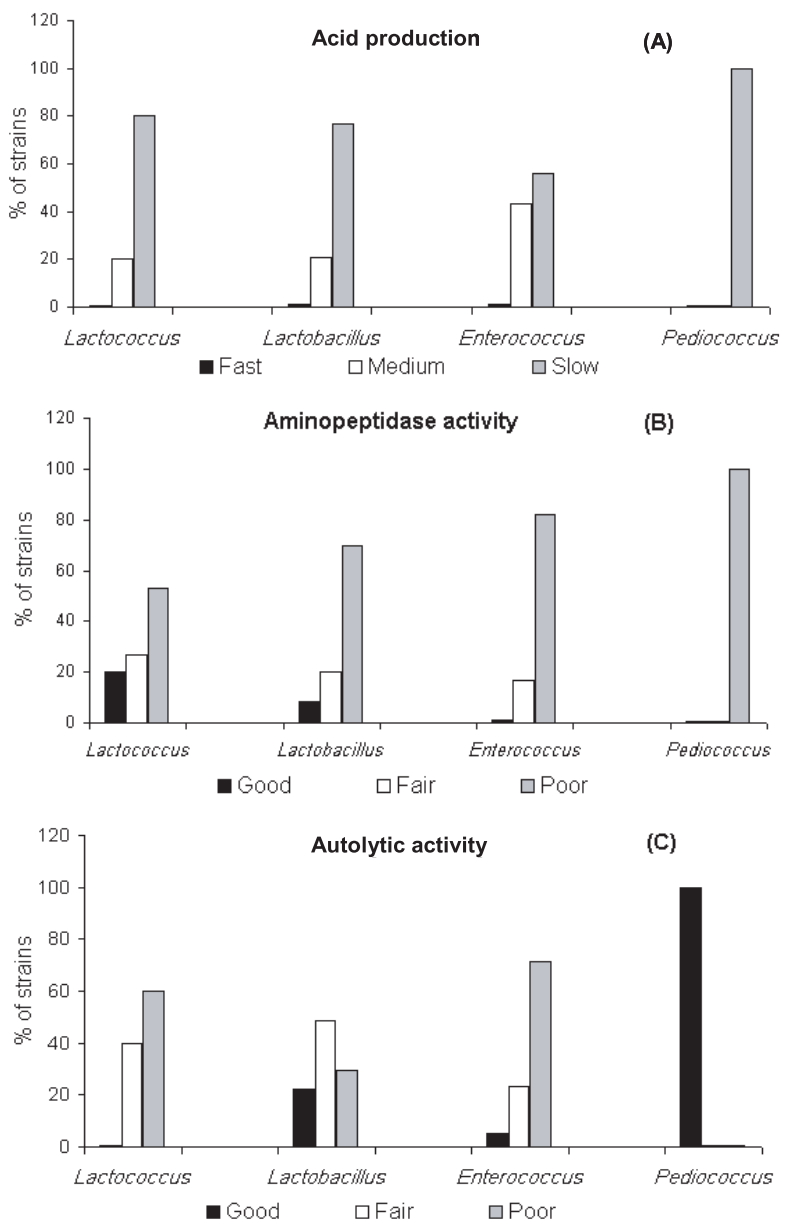

Figure 1. Percentage of strains according to their technological characteristics. (A) fast-, mediumand slow-acidifying; when a $\Delta \mathrm{pH}$ of 0.4 units was achieved after $3,3-5$ and $>5 \mathrm{~h}$, respectively. (B) AP activity level of lactococci and pediococci: good, 20-40; fair, 10-19; poor, 0-9. Lactobacilli: good, 60-100; fair, 30-59; poor, 1-29 and enterococci: good, 13-19; fair, 6-13; poor, 0.8-5. (C) autolytic activity level of lactococci and pediococci: good, 25-37; fair, 15-24; poor, 1-14. Lactobacilli: good, 70-96; fair, 40-69; poor, 0-39 and enterococci: good, 35-66; fair, 24-34; poor, 0-22.

of peptidases (enzymes) that require cofactors might be negatively affected by lysis of the cell. It probably depends on the type of enzyme (system) whether lysis will improve the activity and formation of flavour or not. In cheese practice, a balance in starter autolysis should be necessary for optimal cheese flavour development.

\subsubsection{Antagonistic activity}

Twenty-seven percent of the tested strains exhibited antimicrobial activity; $6 \%$ Lactococcus, $8 \%$ Lactobacillus and $13 \%$ of Enterococcus strains (Tab. II). Many LAB are able to produce bacteriocins against the same species or closely related species [27]; 
this antimicrobial activity is probably a consequence of bacteriocin production. Sixty-seven percent of Lactococcus were bacteriocin-producing; $60 \%$ of these strains were subsp. lactis and $7 \%$ were subsp. cremoris. Lactobacillus-producing strains were Lb. rhamnosus $(6.3 \%), L b$. pentosus $(3.1 \%)$, Lb. paracasei $(3.1 \%)$, Lb. fermentum $(2.1 \%)$ and one strain of $L b$. plantarum. Thirty-two percent of enterococci exhibited antagonistic activity: E. faecium (26\%), E. durans (3\%), E. avium (3\%) and one strain of $E$. faecalis. Bacteriocin-producing strains have been used in starter cultures to improve the safety and quality of the cheese [12] and recently used with sensitive adjunct cultures to increase their autolysis in order to accelerate cheese ripening [35]. Further work should identify the antimicrobial compounds produced by strains before applying them in Ras cheese.

\subsubsection{Exopolysaccharides (EPS) production}

Production of EPS is a feature of many strains of LAB which may be bound to the bacterial cell as capsules or diffuse away from the cell as an extracellular slime [10]: $4.3 \%$ of the tested strains were capsule producers, all belonging to lactobacilli (Tab. II). The EPS-forming LAB are used in the dairy industry as a natural biothickener to enhance the rheological quality [25]. The EPS-producing strains will be used to improve the manufacture of low fat cheese to obtain a better mouth feeling, and in Egyptian fermented milks.

\subsection{Production characteristics of strains}

In order to consider any strain as a starter culture, it should meet a number of criteria for the production of the biomass; high yield in fermentation has to be retained easily by centrifugation or microfiltration and must resist lyophilisation with little practical loss of activity if it will distribute as freeze-drying cultures [9]. Most tested strains were able to produce high yield (good and fair) of biomass in fermentation (Tab. III and Fig. 2). Lactobacillus strains
$(85 \%)$ had generally the highest CDW ranging from 1.0 to $2.30 \mathrm{mg} \cdot \mathrm{L}^{-1} ; \mathrm{Lb}$. rhamnosus, Lb. plantarum, Lb. fermentum and E. faecium exhibited high biomass production compared with the others.

The strains showed a good biomass separation when collected by centrifugation; 93\% of Lactococcus, $89 \%$ of Lactobacillus and $97 \%$ of Enterococcus showed a wellformed pellet (e.g., good and fair): see Table III and Figure 2.

The activity of $67 \%$ of Lactococcus, $63 \%$ of Lactobacillus and $77 \%$ of Enterococcus strains was not affected by lyophilisation (Tab. III and Fig. 2). The enterococci had the greatest ability to endure lyophilisation, and $E$. faecium strains were the most resistant strains $(60 \%)$.

\subsection{Flavour of selected strains}

The strains which showed outstanding characteristics were individually grown in milk cultures to determine their flavourforming abilities. Most strains appeared to produce pleasant flavours; e.g., yoghurtlike, sour and creamy, which are usual flavours for fermented milks. Some strains produced different flavours compared with those usual flavours described as specific flavours, such as fruity, fatty acids, sharp, yeasty, sweet, esters, malty, sulphur, old cheese-like, Ras cheese-like, etc. (Tab. IV). Each of the selected strains was found to be able to produce the same flavour attributes in Ras cheese slurries (under publication). The flavour profile of ripened cheese is mainly affected by proteolysis of caseins and in some types also by lipolysis [2] and the typical cheese flavour results from further conversion of amino acids by enzymes of starter bacteria [8]. In our previous study [6], several market artisanal Ras cheese samples, the origin of whose LAB were tested in the present study, were sensorially evaluated and the flavour volatile compounds were identified using purge-and-trap thermal desorption cold-trap gas chromatography mass spectrometry. Sixty-eight volatile compounds have been identified as being responsible for the typical flavour of cheese. The flavour of artisanal cheese is influenced by the associated wild flora 


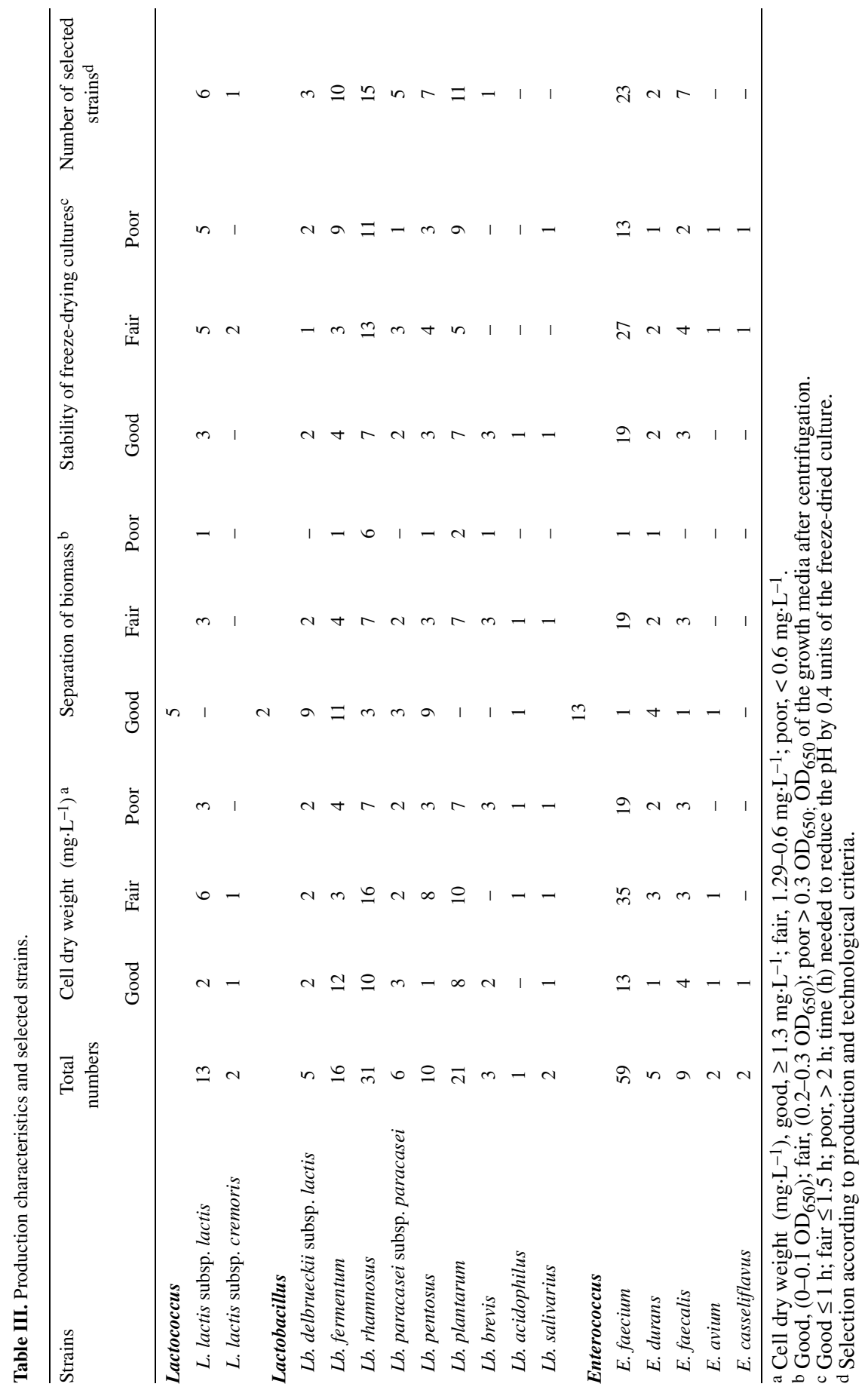



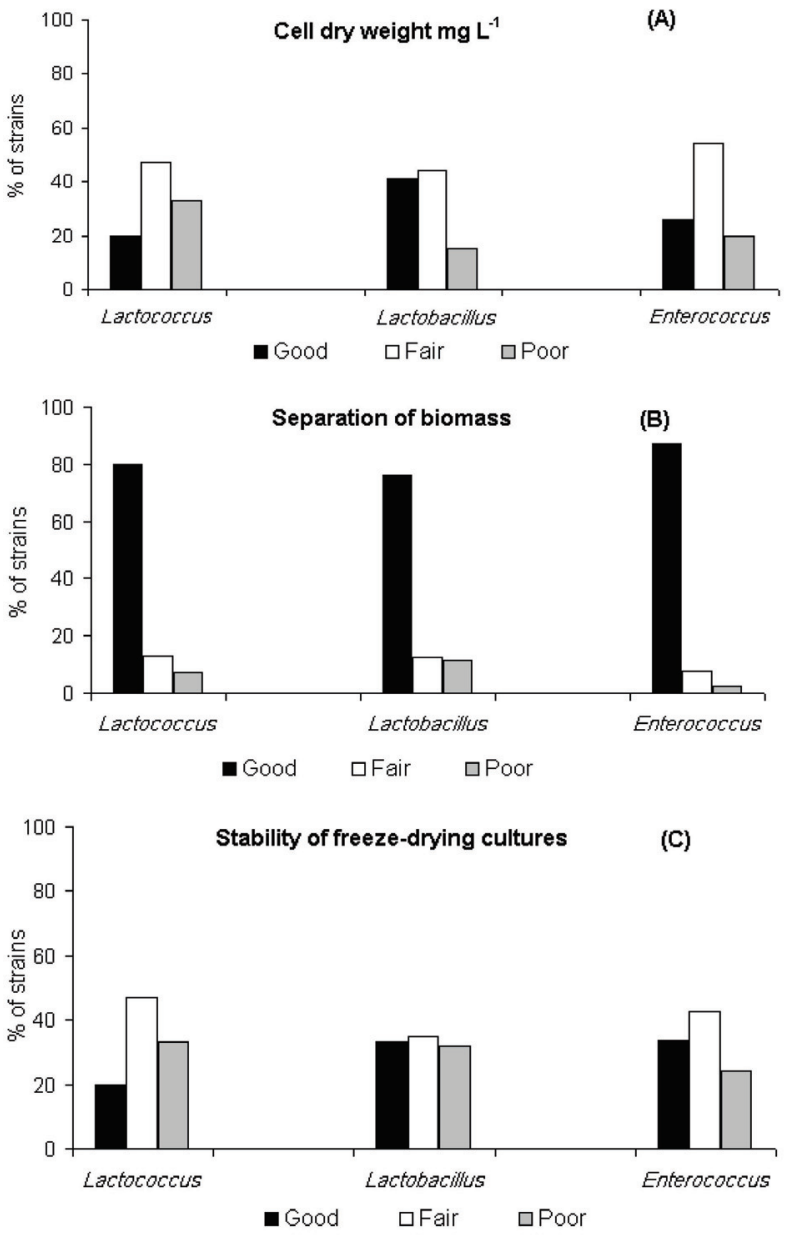

Figure 2. Percentage of strains according to their production characteristics. (A) cell dry weight (CDW mg. $\mathrm{L}^{-1}$ ), good, $\geq 1.3 \mathrm{mg} \cdot \mathrm{L}^{-1}$; fair, $1.29-0.6 \mathrm{mg} \mathrm{L}-1$; poor, $<0.6 \mathrm{mg} \cdot \mathrm{L}^{-1}$. (B) the $\mathrm{OD}_{650}$ of the growth media after centrifugation was used to express the ability of biomass separation; good, $\left(0-0.1 \mathrm{OD}_{650}\right)$; fair, $\left(0.2-0.3 \mathrm{OD}_{650}\right)$; poor $>0.3 \mathrm{OD}_{650}$. $(\mathrm{C})$ the effect of lyophilisation on the culture stability was determined as the difference in time needed to reduce the $\mathrm{pH}$ of reconstituted milk by 0.4 units of the freeze-dried and unfreeze-dried culture; good, $\leq 1 \mathrm{~h}$; fair, $\leq 1.5 \mathrm{~h}$; poor, $>2 \mathrm{~h}$.

which include mesophilic and thermophilic LAB and the flavour-forming abilities are varied between these microorganisms [32]. The tested LAB harbour active amino acid convertases which could explain their ability to produce different flavours in milk and in cheese slurries. Therefore, the use of these strains to produce typical Ras cheese from pasteurised milk looks promising.
Ninety-one strains; 7 Lactococcus, 52 Lactobacillus and 32 Enterococcus (Tab. III) were selected according to their production and technological criteria relevant for an application in Ras cheese manufacture. As an example, the characteristics of 37 selected strains are presented in Table IV. Some strains were able to maintain a high activity of two or more technological characteristics together, e.g., two 
Table IV. Characteristics and flavour profile of some selected strains.

\begin{tabular}{|c|c|c|c|c|c|c|c|c|}
\hline Strains & Species & $\begin{array}{c}\text { Acid } \\
\text { production }^{\mathrm{a}}\end{array}$ & $\begin{array}{c}\mathrm{AP} \\
\text { activitya }^{\mathrm{a}}\end{array}$ & $\begin{array}{l}\text { Autolytic } \\
\text { activitya }\end{array}$ & $\begin{array}{l}\text { Growth in } \\
6.5 \% \text { salt }\end{array}$ & $\begin{array}{l}\text { Bacteriocin } \\
\text { production }\end{array}$ & EPS & Flavour description ${ }^{b}$ \\
\hline \multicolumn{9}{|l|}{ Lactococcus } \\
\hline FAAU $17 \mathrm{~L}$ & L. subsp. lactis & Medium & Good & Fair & + & + & - & Sharp, acid (4), yoghurt-like \\
\hline FAAU 19L & L. subsp. lactis & Slow & Good & Fair & + & + & - & Cheese-like, flat \\
\hline FAAU 67L & L. subsp. lactis & Medium & Fair & Fair & + & + & - & Sweet (1), Laban Rayeb-like ${ }^{c}$ \\
\hline FAAU 71L & L. subsp. lactis & Slow & Good & Fair & - & + & - & Strong, acid (3), yoghurt-like \\
\hline FAAU 1M & L. subsp. lactis & Medium & Poor & Fair & - & + & - & Yeasty, sharp, acid (3), cheese-like \\
\hline FAAU $2 \mathrm{M}$ & L. subsp. lactis & Slow & Fair & Poor & - & - & - & Flat, fermented milk-like \\
\hline FAAU 6M & $\begin{array}{l}\text { L. subsp. } \\
\text { cremoris }\end{array}$ & Slow & Good & Fair & + & - & - & Diacetyl, ester, fruity (1) \\
\hline \multicolumn{9}{|l|}{ Lactobacillus } \\
\hline FAAU 119th & $\begin{array}{l}\text { delb. subsp. } \\
\text { lactis }\end{array}$ & Fast & Fair & Good & + & - & - & Sour (4), fatty (2), yoghurt-like \\
\hline FAAU 121th & $\begin{array}{l}\text { delb. subsp. } \\
\text { lactis }\end{array}$ & Fast & Fair & Good & + & - & - & Yoghurt-like, acid (3), sweet (1) \\
\hline FAAU 93th & fermentum & Fast & Fair & Good & + & - & - & Sharp, acid (4), Laban Rayeb-like \\
\hline FAAU $2 \mathrm{ka}$ & fermentum & Slow & Poor & Fair & + & - & + & Old cheese-like, bitter (2), gassy \\
\hline FAAU 53R & fermentum & Medium & Poor & Good & + & - & - & Acid (1), Ras cheese-like \\
\hline FAAU 41M & fermentum & Slow & Poor & Good & + & + & - & Farm cheese-like \\
\hline FAAU 5M2 & rhamnosus & Slow & Good & Fair & + & - & + & Creamy, slimy (2), acid (3), ester \\
\hline FAAU 91st & rhamnosus & Slow & Fair & Fair & + & - & - & Farm cheese-like \\
\hline FAAU 97st & rhamnosus & Medium & Fair & Poor & + & - & - & Gassy, sour (2), cheese-like \\
\hline FAAU $115 \mathrm{st}$ & rhamnosus & Medium & Good & Fair & + & + & - & Laban Rayeb-like, acid (1) \\
\hline FAAU $48 \mathrm{R}$ & $\begin{array}{l}\text { para. subsp. } \\
\text { pracasei }\end{array}$ & Medium & Poor & Fair & + & + & - & Mild yoghurt, sour (2) \\
\hline FAAU 36M & $\begin{array}{l}\text { para. subsp. } \\
\text { pracasei }\end{array}$ & Medium & Good & Fair & + & + & + & Ras cheese-like, sweet (1), acid (1) \\
\hline FAAU $105 \mathrm{st}$ & pentosus & Slow & poor & Fair & + & - & - & Sulphur, gassy, acid (1), farm cheese \\
\hline FAAU $123 \mathrm{st}$ & pentosus & Slow & poor & Fair & + & - & - & Farm cheese-like, acid (1) \\
\hline FAAU $117 \mathrm{st}$ & plantarum & Medium & Fair & Fair & + & + & - & Malty (1), sour (4) \\
\hline FAAU 118 st & plantarum & Medium & Poor & Fair & + & - & - & Gassy, acid (1) \\
\hline FAAU 40M & plantarum & Slow & Poor & Good & + & - & - & Creamy, sweet (1), flat \\
\hline FAAU 98st & plantarum & Slow & Poor & Fair & + & - & - & Fresh yoghurt-like, creamy (1) \\
\hline FAAU $127 \mathrm{st}$ & brevis & Slow & poor & Fair & + & - & - & Yoghurt-like, acid (2) \\
\hline FAAU 132st & acidophilus & Medium & Good & poor & + & - & - & Old yoghurt-like, strong acid (4) \\
\hline \multicolumn{9}{|l|}{ Enterococcus } \\
\hline FAAU 291E & faecium & Slow & Good & Fair & + & - & - & Sharp, gassy, Ras cheese-like \\
\hline FAAU 398E & faecium & Medium & Fair & Poor & + & + & - & Yoghurt-like \\
\hline FAAU $405 \mathrm{E}$ & faecium & Medium & Fair & Poor & + & + & - & Sweet (2), fatty (1), Laban-Rayeb-like \\
\hline FAAU $411 \mathrm{E}$ & faecium & Fast & Poor & Fair & + & - & - & Yoghurt-like, sweet (1), fatty (1) \\
\hline FAAU $361 \mathrm{E}$ & durans & Slow & Poor & Fair & + & + & - & Sulphur (1), bitter (2) \\
\hline FAAU 374E & durans & Slow & Poor & Fair & + & + & - & Flat, sweet (2), Laban Rayeb-like \\
\hline FAAU $280 \mathrm{E}$ & avium & Slow & Fair & Fair & + & - & - & Flat, yoghurt-like \\
\hline FAAU $371 \mathrm{E}$ & faecalis & Medium & Fair & Good & + & + & - & Mild yoghurt, acid (1) \\
\hline FAAU 404E & faecalis & Medium & Fair & Good & + & - & - & Sweet (1), yoghurt-like \\
\hline FAAU 452E & casseliflavus & Slow & Poor & Fair & + & - & - & Fresh curd, yoghurt-like \\
\hline
\end{tabular}

a Acid production, AP and autolytic activity (for level definitions see legends of Tab. II and Fig. 1).

$\mathrm{b}$ Flavour intensity on scale from (1-4): 1: slightly, 2: moderate, 3: strong, 4: very strong.

c Kind of Egyptian fermented milk (for description see El-Gendy, [16]). 
strains, Lb. fermentum (41M) and E. faecalis (371E), exhibited good autolytic activity and showed an antagonistic effect. Five strains, 3 Lc. lactis subsp. lactis (17L, 19L and $71 \mathrm{~L}), L b$. rhamnosus (5M2) and $L b$. paracasei subsp. paracasei $(36 \mathrm{M})$, were able to produce high AP activity and showed an antagonistic effect. Three strains, 2 Lb. delbrueckii subsp. lactis (119th and 121 th) and $L b$. fermentum (93th) showed a fast acidification, good autolytic activity and fair AP activity. Moreover, the $L b$. paracasei subsp. paracasei $(36 \mathrm{M})$ was able to produce bacteriocin, EPS and had high AP, fair autolytic activity and medium acidification activity. Two lactococci strains, $17 \mathrm{~L}$ and $67 \mathrm{~L}$, were salt-tolerant $(6.5 \%$ $\mathrm{NaCl}$ ), showed antagonistic effect, good AP activity and fair autolytic activity. These strains are valuable for practical application for different purposes, as starter, adjunct and protective cultures.

\section{CONCLUSION}

Our investigation discovered the pool of LAB associated with traditional Ras cheese, and their biochemical and production properties, which are relevant to their application as starter cultures. Ninety-one strains: 7 Lactococcus, 52 Lactobacillus and 32 Enterococcus, were selected and could be used in Ras cheese manufacture according to their technological criteria, salt tolerance, ability to grow at $40-45^{\circ} \mathrm{C}$, acid production, proteolytic activity, flavour and bacteriocin production. The production criteria were also taken into account: all selected strains were resistant to lyophilisation conditions, showed high yield of biomass in fermentation and a good separation after centrifugation. Selected strains are currently being investigated in pilot-scale cheese trials as single and mixed cultures to improve the quality and safety of Ras cheese.

\section{REFERENCES}

[1] Abou-Donia S.A., Recent development in Ras cheese research, A review, Egypt. J. Dairy Sci. 30 (2002) 155-166.
[2] Adda J., Flavours of dairy products, in: Birch G.G., Lindley M.G. (Eds.), Developments in food flavours, Elsevier Applied Sci., London, UK, 1986, pp. 151-172.

[3] Awad S., El Attar A., Ayad E.H.E., El-Soda M., Characterisation of Egyptian market Ras cheese. 1. Sensory evaluation, rheological, physico-chemical properties and microbiological analysis, Egypt. J. Dairy Sci. 31 (2003) 289-303.

[4] Ayad E.H.E., Characterisation of lactococci isolated from natural niches and their role in flavour formation of cheese, $\mathrm{PhD}$ thesis, Wageningen Agricultural University, Wageningen, The Netherlands, 2001.

[5] Ayad E.H.E., Verheul A., Bruinenberg P., Wouters J.T.M., Smit G., Starter culture development for improving the flavour of Proosdij-type cheese, Int. Dairy J. 13 (2003) 159-168.

[6] Ayad E.H.E., Awad S., El Attar A., De Jong C., El-Soda M., Characterisation of Egyptian Ras cheese. 2. Flavour formation, Food Chem. (2003) 553-561.

[7] Bizzarro R., Tarelli G.T., Giraffa G., Neviani E., Phenotypic and Genotypic characterization of lactic acid bacteria isolated from pecorino tosacano cheese, Italian J. Food Sci. 12 (2000) 303-316.

[8] Broome M.C., Limsowtin G.K.Y., Starter peptidase activity in maturing cheese, Aust. J. Dairy Technol. 5 (1998) 79-82.

[9] Buckenhuskes H.J., Selection criteria for lactic acid bacteria to be used as starter cultures for various food commodities, FEMS Microbiol. Rev. 12 (1993) 253.

[10] Cerning J., Exocellular polysaccharides produced by lactic acid bacteria, FEMS Microbiol. Rev. 87 (1990) 113-130.

[11] Dako E., El-Soda M., Vuillemard J.C., Simard R.E., Autolytic properties and aminopeptidase activities of lactic acid bacteria, Food Res. Int. 28 (1995) 503.

[12] Delves-Broughton J., Blackburn P., Evans R.J., Hugenholtz J., Applications of the bacteriocin, nisin, Antonie van Leeuwenhoek 69 (1996) 193-202.

[13] De Man J., Rogosa M., Sharpe E., A medium for the cultivation of lactobacilli, J. of Appl. Bacteriol. 23 (1960) 130-135.

[14] Egyptian Standards For Hard cheese, part 5: Ras cheese, ES: 1007/2001. Ministry of Industry and Technological Development, Egypt (2001). 
[15] El-Abed M.M., El-Batawy N.A., Younes N.A., El-Tawel M.S., Utilization of Goat's milk in marking Ras cheese, Egypt. J. Dairy Sci. 20 (1992) 91.

[16] El-Gendy S.M., Some traditional fermented dairy products in Egypt, Egypt. J. Dairy Sci. (2001) 465-479.

[17] El-Attar A., Osman G., Omran N., El Despuky Z., Abd El Azeim S., El-Soda M., Isolation and identification of lactic acid strains isolated from different Egyptian cheeses, in: Proc. of the 9th Egyptian Conf. for Dairy Science and technology, 9-11 October, Cairo, Egypt, 2004, pp. 339-351.

[18] El-Soda M., Desmazeaud M., Les peptidehydrolase des Lactobacillus du groupe Thermobacterium. 1. Mise en evidence de ces activités chez Lactobacillus helveticus, $L$. lactis et L. bulgaricus, Can. J. Microbiol. 28 (1982) 1181-1188.

[19] El-Soda M., Farkye N., Vuillemarad J., Simard R., Olson N., El Kholy W., Dako E., Medrano E., Gaber M., Lim L., Autolysis of lactic acid bacteria. Impact on flavour development in cheese, in: Food flavour: Generation analysis and process influence, Charalambous G. (Ed.), Elsevier science B.V. Amsterdam, The Netherlands, 1995, pp. 2205-2223.

[20] El-Soda M., El-Ziney M., Awad S., Osman G., Omran N., Gamal G., Ezzat N., El-Shafei H., A culture collection of lactic acid bacteria isolated from raw milk and traditional Egyptian dairy products, Egypt. J. Dairy Sci. 31 (2003) 23-41.

[21] Fortina M.G., Nicastro G., Carminati D., Neviani E., Manachini P.L., Lactobacillus helveticus heterogeneity in natural cheese starters: The diversity in phenotypic characteristics, J. Applied Microbiol. 84 (1998) $72-80$.

[22] Franz C.M.A.P., Holzapfel W.H., Stiles M.E., Enterococci at the crossroads of food safety? A Review, Int. J. Food Microbiol. 47 (1999) 1-24.

[23] Geis A., Singh J., Teuber M., Potential of lactic streptococci to produce bacteriocin, Appl. Environ. Microbiol. 45 (1983) 205211.

[24] Gerhardt P., Diluents and biomass measurement, in: Gerhardt P., Murray R.G., Costilow R.N., Nester E.W., Wood W.A., Krieg N.R., Phillips G.B. (Eds.), Manual of Methods for General Bacteriology, American Society for Microbiology, Washington, DC, 1982, pp. 504-507.
[25] Hassan A., Corredig M., Frank J.F., El-Soda M., Microstructure and rheology of an acidcoagulated cheese (Karish) made with an exopolysaccharide-producing Streptococcus thermophilus strain and its exopolysaccharide non-producing genetic variant, J. Dairy Res. 71 (2004) 116-120.

[26] Hofi A.A., Yossef E.H., Ghoneim M.A., Tawab G.A., Ripening changes in Cephalotyre "Ras" cheese manufactured from raw and pasteurized milk with special reference to flavour, J. Dairy Sci. 53 (1970) 1207 1212.

[27] Jack R.W., Tagg J.R., Ray B., Bacteriocins of gram-positive bacteria, Microbiol. Rev. 59 (1995) 171-200.

[28] Kandler O., Weiss N., Genus Lactobacillus. Beijerink 1901, 212AL, in: Sneath P.A., Mair N.S., Sharpe M.E., Holt J.G. (Eds.), Bergey's Manual of Systematic Bacteriology, Vol. 2., The Williams and Wilkins Co., Baltimore, USA, 1986, pp. 1209-1234.

[29] Knoshaug E.P., Ahlgrent J.A., Trempy J.E., Growth associated exopolysaccharide expression in Lctococcus lactis subsp. cremoris ropy 352, J. Dairy Sci. 83 (2000) 633.

[30] Law J., Haandrikman A., Proteolytic enzymes of lactic acid bacteria, Int. Dairy J. 7 (1997) 1-11.

[31] Miozzari G.F., Nuederberger P., Hütter R., Permeabilization of microorganisms by triton x-100, Analytical Biochem. 90 (1978) 220-233.

[32] Olson N.F., The impact of lactic acid bacteria on cheese flavor, FEMS Microbiol. Rev. 87 (1990) 131-148.

[33] Phelan J.A., Renaud L., Fox P.F., Some nonEuropean cheese varieties, in: Fox P.F. (Ed.), Cheese: chemistry, physics and microbiology, Chapman and Hall, London, UK, 1993, pp. 421-465.

[34] Prescoll L.M., Harley J.P., Klein D.A., Capsules and slime layers - The study of Microbioal structure: Microscopy and specimen preparation, in: Microbiology, United States of America: wmc Brown Publishers, Inc, 1996, pp. 58-59.

[35] Ross P., Galvin M., McAuliffe O., Morgan S., Ryan M., Twomey D., Meaney W., Hill C., Developing applications for lactococcal bacteriocins, Antonie van Leeuwenhoek 72 (1999) 1.

[36] Sarantinopoulos P., Andrighetto C., Georgalaki M.D., Rea M.C., Lombardi A., Cogan T.M., Kalantzopoulos G., Tsakaliou E., Biochemical 
properties of enterococci relevant to their technological performance, Int. Dairy J. 11 (2001) 621-647.

[37] Smit G., Smit B.A., Engels W.J.M., Flavour formation by lactic acid bacteria and biochemical flavour profiling of cheese products, FEMS Microbiol. Review 29 (2005) 591-610.

[38] Stanley G., Cheeses, in: Wood B. (Ed.), Microbiology of fermented foods, Blackie Academic and Professional, London and New York, 1998, pp. 263-307.

[39] Terzaghi B.K., Sandine W.E., Improved medium for lactic streptococci and their bacteriophage, Appl. Bacteriol. 29 (1975) 807.
[40] Thiboutot H., Dako E., El Soda M., Vuillemard J.C., Power N., Simard R.E., Influence of heat and freeze shocking on the autolysis and peptidase activities of Lactobacillus casei, Milchwissenschaft 50 (1995) 448452.

[41] Vukasinovic M.F., Topisirovic L., Characteristics of natural isolates lactic acid bacteria selected for construction of starter cultures for Semi-hard cheese of the trapist type, Acta Veterinaria (Beograd) 51 (2001) 53-66.

[42] Walstra P., Geuts T.J., Noomen A., Jellema A., Van Boekel M.A., Lactic fermentations, in: Dairy technology: Principles of milk properties and processes, Marcel Dekker, Inc., New York, USA, 1999, pp. 325-352. 